\title{
Efektivitas Penggunaan Media Penyuluhan \\ (Kasus pada Kelompok Ranca Kembang Desa Luhur Jaya Kecamatan Cipanas Kabupaten Lebak Provinsi Banten)
}

\author{
Effectiveness Use Of Extension Media \\ (case study of ranca kembang group in luhur jaya village - cipanas, \\ lebak - banten) \\ Ani Leilani ${ }^{凶}$, Nayu Nurmalia, Muh. Patekkai \\ Sekolah Tinggi Perikanan, Jurusan Penyuluhan Perikanan \\ Jalan Cikaret Nomor 2 Bogor 16001, Jawa Barat
}

Diterima: 18 februari 2017; Disetujui: 4 Juni 2015

\begin{abstract}
Abstrak
Media penyuluhan merupakan salah satu unsur yang terpenting dalam kegiatan penyuluhan. Penggunaan media massa contohnya, yang harus dipertimbangkan dalam penggunaannya adalah peranannya dalam program penyuluhan, penggunaannya secara efektif. Yang penting adalah efek yang diharapkan, dan cara menggunakannya untuk menjamin agar arti pesan menjadi sejelas mungkin. Pilihan terhadap media massa yang digunakan, dan perbedaan antara media massa dan komunikasi anatar pribadi. Penggunaan media menjadi sangat penting dalam rangka adopsi inovasi oleh pelaku utama perikanan. Dari proses adopsi inovasi dan media yang digunakan juga bisa memperlihatkan tingkat efektifitas masing-masing media. Tujuan dari penelitian ini adalah mengetahui tingkat efektifitas penggunaan media penyuluhan pada kelompok pembudidayaikan Ranca Kembang. Penelitian dilaksanakan pada bulan Januari sampai Februari 2014 yang berlokasi penelitian di Desa Luhur Jaya Kecamatan Cipanas Kabupaten Lebak Provinsi Banten dengan jumlah sample sebanyak 30 orang. Data kemudian dianalisis dengan uji Koefisien Korelasi Pearson. Faktor internal berhubungan dengan faktor eksternal pembudidaya ikan tingkat pendidikan, tingkat kekosmopolitan dan tingkat keinovatifan. Sedangkan faktor eksternal pembudidaya yang berhubungan dengan faktor internal adalah materi penyuluhan, kemasan penyuluhan dan penyajian penyuluhan. Faktor internal pembudidaya ikan (umur, pendidikan, tingkat kebutuhan, tingkat kekosmolitan dan tingkat keinovatifan) tidak menunjukkan hubungan dengan penggunaan media penyuluhan baik berupa media cetak maupun media tertayang. Faktor Eksternal yang mempunyai hubungan sangat erat dengan penggunaan media penyuluhan yaitu untuk materi berhubungan erat dengan penggunaan media brosur dan film. Faktor eksternal kemasan media berhubungan dengan penggunaan media peta singkap. Sedangkan faktor eksternal penyajian media penyuluhan berhubungan erat dengan penggunaan media penyuluhan berupa leaflet, peta singkap dan majalah.
\end{abstract}

Kata Kunci: media penyuluhan, adopsi inovasi, kelompok, pelaku utama.

\begin{abstract}
Extension Media is one of the most important elements in the extension activities. The use of mass media for example, should be considered in its use is its role in outreach programs, the user effectively. What is important is the expected effects, and how to use it to ensure that the meaning of the message becomes clear as possible. The choice of the mass media is used, and the difference between the mass media and communications private anatar. The use of media is very important in the context of the adoption of the innovation by the fisheries main actors. Of the adoption process of innovation and media used can also show the level of effectiveness of each media. The purpose of this study was to determine the effectiveness of the use of media outreach in "Ranca Kembang" Group. The research was conducted from January to February 2014, located in the village of Cipanas Luhur Jaya District of Lebak regency of Banten province with 30 total sample. Data were analyzed with Pearson correlation coefficient. Internal factors relate to external factors fish farmer education level, the level and degree of keinovatifan kekosmopolitan. While external factors related to the growers of internal factor is the extension materials, packaging and presentation extension extension. Internal factors fish farmers (age, education, level of need, the level, innovative, cosmopolit rate) showed no association with the use of media outreach in the form of print media as well as media tertayang. External factors that have a relationship very closely with the use of media outreach for the material that is closely associated with the use of brochures and films. External factors relate to the use of the media package media map uncover. While external factors presentation of media education is closely linked to the use of media outreach in the form of leaflets, maps and magazines uncover.
\end{abstract}

Keyword: extension media, adoption of innovation, group, main actor

\footnotetext{
$\triangle$ Penulis korespondensi

Alamat surel: anileilani@yahoo.com

Pendahuluan
} 
Latar Belakang

Penyelenggaraan penyuluhan merupakan proses pembelajaran bagi pelaku utama serta pelaku usaha agar mereka mau dan mampu menolong serta mengorganisasikan dirinya dalam mengakses informasi pasar, teknologi pemodalan, dan sumberdaya lainnya sebagai upaya untuk meningkatkan produktivitas, efisiensi usaha, pendapatan dan kesejahteraannya, serta meningkatkan kesadaran dalam pelestarian fungsi lingkungan hidup.

Penyelenggaraan penyuluhan diharapkan mampu memberikan suatu perubahan sosial baik pada individu maupun masyarakat agar dapat terwujud perubahan yang lebih baik sesuai dengan yang diharapkan. Dari pelaksanaan penyuluhan tersebut diharapkan masyarakat mampu mendapatkan atau mengembangkan pengetahuan, keterampilan serta perilakunya maupun keluarganya. Oleh karena itu, proses dan penyelenggaran penyuluhan harus dibuat sedemikian rupa agar masyarakat mau, mampu, tertarik, dan ikut serta dalam penyelenggaraan penyuluhan sehingga mampu mewujudkan harapan yang diinginkan.

Salah satu unsur penting yang perlu diperhatikan dalam penyelenggaraan penyuluhan adalah pemilihan Media penyuluhan. Dimana media penyuluhan merupakan segala sesuatu yang berisi pesan atau informasi yang dapat membantu kegiatan penyuluhan. Media penyuluhan perikanan digunakan dalam rangka mengefektifkan penyampaiaan pesan pada proses komunikasi antara penyampai pesan dengan masyarakat sasaran penyuluhan. Pada faktanya, proses komunikasi dalam hal ini penyampaian informasi yang hanya menggunakan kata-kata atau tanpa media jarang bisa dimengerti oleh sasaran penyuluhan sehingga diperlukan adanya media penyuluhan yang mampu membantu dalam proses penyampaian pesan

Penggunaan media setidaknya mampu memberikan banyak manfaat seperti; mempermudah dan mempercepat sasaran dalam menerima pesan, mampu menjangkau sasaran yang lebih luas, alat informasi yang akurat dan tepat, dapat memberikan gambaran yang lebih kongkrit, baik unsur gambar maupun geraknya, lebih atraktif dan komunikatif, dapat menyediakan lingkungan belajar yang amat mirip dengan lingkungan kerja sebenarnya, memberikan stimulus terhadap banyak indera, dapat digunakan sebagai latihan kerja dan latihan simulasi.

Pemilihan penggunaan media penyuluhan merupakan faktor yang mutlak diperlukan karena mampu mempengaruhi efektivitas kegiatan penyuluhan yang dilaksanakan. Sebagai contoh, peningkatan pengetahuan, keterampilan, dan sikap masyarakat merupakan hasil suatu proses pembelajaran dalam kegiatan penyuluhan, dimana keberhasilan tersebut sangat dipengaruhi oleh efektivitas penggunaan media. Oleh karenanya, dalam rangka mengefektifkan penggunaan media penyuluhan seyogyanya ada beberapa hal yang diperlukan dalam pemilihan media penyuluhan yakni: tujuan perubahan, karakteristik sasaran, strategi komunikasi, isi pesan, biaya dan karakteristik wilayah.

Berdasarkan pertimbangan tersebut, penelitian yang akan dilaksanakan pada kelompok Ranca Kembang Kecamatan Cipanas Kabupaten Lebak adalah efektifitas penggunaan media penyuluhan terhadap peningkatan kemampuan pelaku utama. Dari hasil penelitian tersebut, nantinya diharapkan akan diperoleh hasil dan kajian tentang penggunaan media penyuluhan yang efektif yang diadasarkan pada karakteristik penyelenggaran penyuluhan baik dari aspek 
sasaran, pengirim pesan, isi pesan serta kondisi wilayah tersebut.

Tujuan dari penelitian ini adalah mengetahui tingkat efektifitas penggunaan media penyuluhan pada kelompok pembudidaya ikan Ranca Kembang Desa Luhur Jaya Kecamatan Cipanas Kabupaten Lebak Provinsi Jawa Barat.

\section{Kerangka Pemikiran}

Kemampuan pelaku utama dapat ditingkatkan melalui penyampaian informasi tentang pengetahuan dan keterampilan yang terkait dengan usaha yang dilakukan oleh pelaku utama. Penyampaian informasi/pesan bagi pelaku utama tersebut dapat dilakukan dengan bantuan penggunaan media penyuluhan sebagai alat dalam menciptakan efektivitas dan peningkatan kemampuan. Oleh karena itu, perlu diperhatikan satu hal yaitu penggunaan dan pemilihan media penyuluhan yang sesuai dengan selera dan kepentingan/ kebutuhan serta menarik bagi sasaran sehingga mampu mempercepat proses adopsi dan difusi suatu inovasi.

Berdasarkan uraian di atas, maka perlu ditelaah hubungan antara faktor-faktor yang mempengaruhi kemampuan pelaku utama dengan penggunaan media penyuluhan baik faktor internal maupun faktor eksternal.

\section{Hipotesis Penelitian}

Berdasarkan kerangka pemikiran yang telah dikemukan, maka hipotesis penelitian yang akan diuji dalam penelitian ini adalah sebagai berikut:

1. Terdapat hubungan antara faktor internal pelaku utama dengan faktor eksternal pembudidaya ikan

2. Terdapat hubungan antara faktor internal dengan penggunaan media penyulu han

3. Terdapat hubungan antara faktor eksternal pelaku utama dengan penggunaan media penyuluhan

\begin{tabular}{|l|}
\hline Karakteristik Internal \\
Pembudidaya \\
\hline • Umur \\
• Tingkat pendidikan \\
- Tingkat kebutuhan informasi \\
- Tingkat kekosmopolitan \\
- Tidak keinovatifan \\
\hline
\end{tabular}

\begin{tabular}{|l|}
\hline Karakteristik Eksternal \\
\hline - Materi penyuluhan \\
- Kemasan media penyuluhan \\
- Penyajian media penyuluhan \\
\hline
\end{tabular}

Gambar 1. Hubungan antara faktor internal dan eksternal pelaku utama dengan penggunaan media penyuluhan 


\section{Metodologi}

Waktu dan Lokasi

Penelitian dilaksanakan pada bulan Januari sampai Februari 2014. Lokasi penelitian pada kelompok Ranca Kembang Desa Luhur Jaya Kecamatan Cipanas Kabupaten Lebak Provinsi Banten dengan pertimbangan bahwa kelompok tersebut merupakan binaan Pusat Penyuluhan BPSDMKP dan Sekolah Tinggi Perikanan Jurusan Penyuluhan Perikanan Bogor.

\section{Rancangan Penelitian}

Penelitian yang dilakukan adalah penelitian kasus yang bersifat deskriptif korelasional yaitu menjelaskan hubungan antara variable-variabel penelitian melalui pengujian hipotesis (Singarimbun dkk, 1989). Studi korelasional dilakukan untuk menguji hubungan antara faktor internal dan faktor eksternal kelompok pembudidaya dengan penggunaan media penyuluhan terhadap kemampuan kelompok.

Populasi dan Sampel

Populasi pada penelitian ini adalah seluruh anggota kelompok pembudidaya Ranca Kembang Desa Luhur Jaya Kecamatan Cipanas Kabupaten Lebak. Sampel yang diambil secara sensus dari seluruh populasi sebanyak 30 Orang.

Pengumpulan Data

Pengumpulan data penelitian dilaksanakan selama dua bulan. Data yang dikumpulkan dalam penelitian ini terdiri dari dua jenis data yaitu data primer dan data sekunder yang diperoleh dengan cara: Menggunakan kuesioner, Wawancara Pengumpulan data sekunder melalui kajian-kajian pustaka yang berkaitan dan relevan dengan penelitian ini, dan Melakukan observasi langsung yaitu berupa pengamatan langsung di lapangan.

Analisa Data
Data dan hasil penelitian yang telah dikumpulkan yang bersifat kualitatif ditabulasi dan dianalisis secara deskriptif, sedangkan data kuantitatif diuji dengan uji statistik non parametrik. Keeratan hubungan antara peubah (hubungan antara variabel bebas dengan variabel tidak bebas) digunakan Uji korelasi rank Spearman (rs) (Siegel, 1997)

\section{Hasil dan Pembahasan}

Karakteristik Internal Pembudidaya Ikan

Kapasitas secara umum diartikan sebagai kemampuan yang dimiliki oleh seseorang. Namun demikian, sebenarnya kapasitas memiliki arti yang lebih luas tidak hanya sekedar sebagai suatu bentuk kemampuan. Liou (2008) menyatakan bahwa kapasitas mengarah pada konteks kinerja (performance), kemampuan (ability), kapabilitas (capability) dan potensi kualitatif suatu objek atau orang. Selaras dengan hal tersebut Milen (2001) mendefinisikan kapasitas sebagai kemampuan individu, organisasi atau sistem untuk menjalankan secara tepat fungsi-fungsinya secara efektif, efesien, dan berkelanjutan. Lebih lanjut dinyatakan bahwa kapasitas berhubungan dengan kinerja yang ditetapkan, dan ketepatan dalam menjalankan fungsi dan tugas, misalnya sejauh mana kontribusi seseorang dalam mencapai tujuan yang ditetapkan.

Karakteristik responden yang diamati dalam penelitian ini meliputi faktor internal yaitu umur, tingkat pendidikan, tingkat kebutuhan, tingkat kekosmopolitan, dan tingkat keinovatifan. Karakterisitik sasaran ini berdasarkan pada beberapa referensi yang mencirikan masyarakat yang dinamis, Masyarakat yang mampu dengan cepat mengadopsi inovasi dapat dicirikan oleh beberapa hal seperti: Banyak melakukan kontak dengan penyuluh dan orang-orang lain di luar kelompok sosialnya; Berpartisipasi aktif pada banyak organisasi; Memanfaatkan secara intensif 
informasi dari media massa, terutama yang menyangkut informasi dari para ahlinya; Cukup berpendidikan; Memiliki pendapatan dan taraf hidup yang relatif tinggi; Memiliki sikap yang positif terhadap perubahan; Memiliki aspirasi tinggi bagi dirinya sendiri serta anak-anaknya (Van Den Ban dan Hawkins, 1999). Sebaran karakteristik internal responden seperti pada Tabel 1.

Hasil penelitian pada Tabel 1 menunjukkan bahwa umur responde berkisar antara 27 - 65 tahun dengan umur rata-rata 44,8 tahun. Umur responden didominasi pada umur sedang ( 34,9- 54,7) tahun. Umur merupakan suatu aspek yang berhubungan dengan kemampuan fisik maupun psikologis seseorang. Berdasarkan data umur tersebut menunjukkan bahwa responden sebagai pembudidaya ikan kelompok Ranca Kembang Kecamatan Cipanas Kabupaten Lebak sebanyak $83 \%$ masih tergolong usia produktif yaitu antara (27-54,7) tahun. Umur responden dengan kategori usia tua (>54,7 tahun) hanya $17 \%$.

Berdasarkan Tabel 1. menunjukkan bahwa responden memiliki tingkat pendidikan yang

Tabel 1. Sebaran karakteristik Internal Responden berbeda-beda mulai dari tamat SD mencapai 10 orang (33\%), sedangkan SLTP yaitu 9 orang petani $(30 \%)$ dan SLTA yaitu 11 orang (37\%). Pengkategorian tingkatan SD, SLTP dan SLTA dinilai dapat membedakan wawasan, pengetahuan dan cara berfikir seseorang terutama dalam menyerap materi usaha budidaya perikanan dengan penggunaan berbagai media penyuluhan. Gambaran tingkat pendidikan pembudidaya anggota kelompok menunjukkan seluruh anggota memiliki kemampuan baca-tulis, berarti memungkinkan untuk menyerap informasi dari media sesuai kebutuhan untuk kemajuan usahanya.

Tingkat kapasitas yang ada pada diri seorang pembudidaya ikan dipengaruhi oleh faktor yang berasal dari dalam dirinya maupun dari lingkungan di luar dirinya, terutama dari lingkungan kelompok tempat dirinya hidup. Karateristik personal sebagai faktor internal akan mempengaruhi kemampuan seseorang dalam menjalankan pekerjaannya. Dalam hal ini termasuk petani, nelayan, maupun pembudidaya ikan yang melakukan usahanya. Beberapa penelitian menunjukkan hal ini, diantaranya yang

\begin{tabular}{|c|c|c|c|c|c|}
\hline NO & $\begin{array}{c}\text { Karakteristik } \\
\text { Internal } \\
\text { Responden }\end{array}$ & Katagori & $\mathbf{N}$ & $\begin{array}{c}\text { Persentase } \\
\mathbf{n}=\mathbf{3 0} \\
(\%)\end{array}$ & Interval \\
\hline 1 & Umur & $\begin{array}{l}\text { Muda }(<34,9 \text { thn } \\
\text { Sedang }(34,9-54,7 \text { thn }) \\
\text { Tinggi }(>54,7 \text { thn })\end{array}$ & $\begin{array}{c}3 \\
22 \\
5\end{array}$ & $\begin{array}{l}10 \\
73 \\
17\end{array}$ & $27-65$ thn \\
\hline 2 & $\begin{array}{l}\text { Tingkat } \\
\text { Pendidikan }\end{array}$ & $\begin{array}{l}\text { Rendah SD } \\
\text { Sedang SMP } \\
\text { Tinggi SMA }\end{array}$ & $\begin{array}{c}10 \\
9 \\
11\end{array}$ & $\begin{array}{l}33 \\
30 \\
37\end{array}$ & SD - SMA \\
\hline 3 & $\begin{array}{l}\text { Tingkat } \\
\text { kebutuhan }\end{array}$ & $\begin{array}{l}\text { Ya (3) } \\
\text { Kurang (2) } \\
\text { Tidak (1) }\end{array}$ & $\begin{array}{c}30 \\
0 \\
0\end{array}$ & $\begin{array}{c}100 \\
0 \\
0\end{array}$ & $1-3$ \\
\hline 4 & $\begin{array}{l}\text { Tingkat } \\
\text { Kekosmopolitan }\end{array}$ & $\begin{array}{l}\text { Ya (3) } \\
\text { Kadang-kadang (2) } \\
\text { Tidak (1) }\end{array}$ & $\begin{array}{c}24 \\
6 \\
0\end{array}$ & $\begin{array}{c}80 \\
20 \\
0\end{array}$ & $1-3$ \\
\hline 5 & $\begin{array}{l}\text { Tingkat } \\
\text { Keinovatifan }\end{array}$ & $\begin{array}{l}\text { Ya (3) } \\
\text { Kadang-kadang (2) } \\
\text { Tidak (1) }\end{array}$ & $\begin{array}{c}29 \\
1 \\
0\end{array}$ & $\begin{array}{c}96,7 \\
3,3 \\
0\end{array}$ & $1-3$ \\
\hline
\end{tabular}


dilakukan oleh Chian u dan Tjujii (2005) di Nigeria bahwa usia muda dan pendidikan lebih tinggi cenderung memiliki kemampuan untuk menerapkan inovasi yang diperkenalkan. Demikian pula penelitian Kposowa (1996) di Maryland, Amerika Serikat menunjukkan bahwa luas lahan, pengetahuan, pengalaman usaha, persepsi tentang praktek pemupukan tanah, dan keterampilan teknis mempengaruhi kemampuannya dalam menerapkan pupuk organik dalam usahanya.

Tingkat kebutuhan informasi perikanan terkait dengan kegiatan usaha yang dijalankan, sesuai hasil penelitian pada Tabel 2. menunjukkan bahwa semua responden (100\%) membutuhkan informasi perikanan. Hal tersebut artinya dalam mengelola usahanya pembudidaya anggota kelompok membutuhkan informasi yang sesuai dengan usaha budidaya yang sedang dijalankannya.

Tingkat kekosmopolitan adalah aktivitas seseorang ke luar lokasi atau daerahnya dalam mencari inovasi-inovasi terkait dengan teknologi budidaya ikan. Pembudidaya ikan anggota kelompok Ranca Kembang termasuk pembudidaya ikan dengan tingkat kekosmopolitan yang cukup, data hasil penelitian menunjukan bahwa keaktifan mencari informasi termasuk kategori tinggi sebanyak $80 \%$ dari 30

Tabel 2. Sebaran Karakteristik Eksternal Responden responden. Hal tersebut menunjukkan bahwa anggota kelompok Ranca Kembang respon dan aktif dalam mendapatkan informasi yang berhubungan dengan peningkatan usahanya, selain informasi yang diterima dari penyuluh perikanan. Keaktifan mencari informasi merupakan upaya anggota untuk mendapatkan teknologi usahatani yang baru, baik dari sumbernya langsung (lembaga penelitian), lembaga penyuluhan, pakar, dan kontaktani sebagai pemimpin kelompok.

Tingkat keinovatifan adalah sikap anggota kelompok pembudidaya ikan untuk mau dan menerapkan inovasi yang diperolehnya pada kegiatan usaha. Hasil penelitian menunjukkan bahwa sebagian besar anggota kelompok pembudidaya ikan sebanyak 96,7\% termasuk tingkat keinovatifannya tinggi dan sebanyak 3,3 $\%$ termasuk tingkat keinovatifannya sedang. Hal ini menunjukkan bahwa responden dapat menerima informasi baru yang disampaikan oleh penyuluh.

Dalam kaitannya dengan inovasi, pemuka pendapat harus memenuhi beberapa fungsi di dalam kelompoknya seperti; Meneruskan informasi dari luar kelompoknya; Menafsirkan informasi dari luar atas dasar pendapat dan pengalamannya sendiri; Memberikan contoh untuk ditiru oleh orang-orang di sekitarnya;

\begin{tabular}{|c|l|l|c|c|c|}
\hline No & $\begin{array}{c}\text { Karakteristik } \\
\text { Eksternal } \\
\text { Responden }\end{array}$ & \multicolumn{1}{|c|}{ Kategori } & N & $\begin{array}{c}\text { Persentase } \\
\text { (\%) } \\
\mathbf{n = 3 0}\end{array}$ & Interval \\
\hline 1 & Materi & Ya (3) & 24 & 80 & \\
& penyuluhan & Kadang-kadang (2) & 3 & 10 & $1-3$ \\
& & Tidak (1) & 3 & 10 & \\
\hline 2 & Kemasan media & Selalu (3) & 20 & 66,6 & $1-3$ \\
& penyuluhan & Kadang-kadang (2) & 8 & 26,7 & \\
& & Tidak (1) & 2 & 6,7 & \multirow{2}{*}{$1-3$} \\
\hline 3 & Tingkat & Cukup (3) & 3 & 90 & 10 \\
& penyajian media & Kurang (2) & 0 & 0 & \\
\hline & penyuluhan & Tidak (1) & & \\
\hline
\end{tabular}


Mngukuhkan atau menolak perubahan yang ingin dilaksanakan oleh orang lain. Dengan kata lain, persetujuan atau penolakan atas suatu perubahan ditentukan olehnya; Berpengaruh dalam mengubah norma kelompok. Tidak semua pemuka pandangan melakukan hal yang tersebut diatas. Beberapa pemuka mungkin akan memberikan informasi awal dari proses adopsi inovasi, dan yang lainnya memutuskan untuk mengadopsi atau menolaknya.

\section{Karakteristik Eksternal Pembudidaya Ikan}

Karakteristik responden yang diamati dalam penelitian ini meliputi faktor eksernal yaitu materi penyuluhan, kemasan media dan penyajian media. Pada kegiatan penyuluhan, pengunnaan media penyuluhan memiliki beberapa fungsi menurut Pusat Manajemen Pengambangan SDM Pertanian (2001), Fungsi media penyuluhan khususnya media visual terdiri dari 4 (empat) yaitu:

Fungsi atensi, yaitu menarik dan mengarahkan perhatian sasaran untuk berkonsentrasi kepada isi materi yang berkaitan dengan makna visual yang ditampilkan atau menyertai teks materi. Dengan demikian, kemungkinan untuk memperoleh dan mengingat isi materi semakin besar. Fungsi afektif, media visual dapat terlihat dari tingkat kenikmatan peserta ketika belajar atau membaca teks yang tergambar. Fungsi kognitif, media visual terlihat dari temuan-temuan penelitian yang mengungkapkan bahwa lambang visual atau gambar memperlancar pencapaian tujuan untuk memahami dan mengingat informasi atau pesan yang terkandung dalam gambar. Fungsi kompensatoris, yaitu media visual membantu mengakomodasi peserta dan sasaran yang lemah dan lambat menerima dan memahami isi materi yang disajikan dengan teks atau disajikan secara verbal.

Sebaran karakteristik ekternal responden seperti pada Tabel 2 .

Materi penyuluhan, pada hakekatnya merupakan segala pesan yang ingin dikomunikasikan oleh seorang penyuluh kepada masyarakat penerima manfaatnya (Mardikanto, 2009). Definisi materi penyuluhan pada penelitian ini adalah isi informasi yang diberikan penyuluh kepada responden. Berdasarkan data hasil penelitian sebagian besar responden (80\%) menunjukkan bahwa materi penyuluhan yang diberikan oleh penyuluh adalah materi baru yang dibutuhkan oleh responden. Apapun materi penyuluhan yang disampaikan oleh seorang penyuluh, pertama-tama harus diingat bahwa materi tersebut harus selalu mengacu kepada kebutuhan yang telah dirasakan oleh masyarakat sasarannya artinya materi penyuluhan dapat dilaksanakan sesuai dengan kebutuhan sasaran.

Tabel 3. Hubungan Faktor internal dan Faktor Eksternal Responden

\begin{tabular}{|c|c|c|c|c|c|}
\hline Eksternal & Umur & Pendidikan & $\begin{array}{c}\text { Tingkat } \\
\text { Kebutuhan }\end{array}$ & $\begin{array}{c}\text { Tingkat } \\
\text { Kekosmopolitan }\end{array}$ & $\begin{array}{c}\text { Tingkat } \\
\text { Keinovatfan }\end{array}$ \\
\hline Materi & $-0,061$ & $-0,168$ & A & $0,547^{* *}$ & 0,203 \\
\hline $\begin{array}{l}\text { Kemasan } \\
\text { media }\end{array}$ & 0,021 & $0,365^{*}$ & A & 0,218 & 0,182 \\
\hline $\begin{array}{l}\text { Penyajian } \\
\text { media }\end{array}$ & 0,391 & $0,385^{*}$ & A & 0,111 & $0,156^{*}$ \\
\hline
\end{tabular}


Kemasan media penyuluhan adalah hasil produksi media sesuai selera dan keinginan responden. Data hasil penelitian menunjukkan bahwa sebagian besar responden $(66,6 \%)$ menunjukkan bahwa kemasan media penyuluhan yang digunakan oleh penyuluh dalam kegiatan penyuluhan cukup sesuai dengan keinginan responden.

Tingkat penyajian media penyuluhan adalah kemampuan menyajikan media penyuluhan sesuai dengan jenis media yang digunakan. Berdasarkan hasil penelitian pada Tabel 2 menunjukkan sebagian besar (90\%) responen menyatakan bahwa tingkat penyajian pesan media penyuluhan yang diberikan penyuluh cukup menarik dan mudah untuk dipelajari/dipraktekkan.

Hubung an antara faktor internal dengan faktor eksternal pelaku utama

Hasil analisis hubungan faktor internal dan faktor eksternal pembudidaya ikan (pelaku utama) disajikan pada Tabel 3.

Berdasarkan hasil analisis pada Tabel 3 menunjukkan bahwa umur pembudidaya ikan tidak menunjukkan korelasi (hubungan) yang erat dengan materi, kemasan media dan penyajian media penyuluhan. Pendidikan pembudidaya menunjukkan hubungan yang erat dengan kemasan media dengan korelasi $0,365^{*}$ dan menunjukkan hubungan yang erat penyajian media penyuluhan dengan korelasi 0,385*, sedangkan pendidikan tidak menunjukkan hubungan dengan ma teri penyuluhan.

Tingkat kekosmopolitan menunjukkan hubungan yang erat dengan materi penyuluhan dengan korelasi $0,547 * *$, tetapi tidak menunjukkan hubungan dengan kemasan dengan penyajian media penyuluhan. Faktor internal tingkat keinovatifan pembudidaya berhubungan erat dengan penyajian media dengan korelasi $0,156^{*}$, tetapi tidak menunjukkan hubungan dengan materi dan kemasan media penyuluhan.

Hubungan antara faktor internal dengan penggunaan media penyuluhan

Hasil analisis hubungan faktor internal pembudidaya ikan (pelaku utama) dengan penggunaan media penyuluhan disajikan pada Tabel 4. Berdasarkan data hasil analisis pada Tabel 4 menunjukkan bahwa umur, pendidikan, tingkat kekosmopolitan dan tingkat keinovatifan tidak menunjukkan hubungan (korelasi) dengan penggunaan media penyuluhan baik media cetak berupa brosur, folder, leaflet, peta singkat, koran dan majalah maupun dengan media tertayang yaitu power point dan film.

Hubungan antara faktor eksternal pelaku utama dengan penggunaan media penyuluhan

Tabel 4. Hubungan faktor internal dengan penggunaan media

\begin{tabular}{|c|c|c|c|c|c|c|c|c|}
\hline $\begin{array}{c}\text { Penggunaan } \\
\text { media } \\
\text { F. Internal }\end{array}$ & $\begin{array}{c}\text { Brosu } \\
\mathrm{r}\end{array}$ & Folder & Leaflet & $\begin{array}{c}\text { Peta } \\
\text { singkap }\end{array}$ & $\begin{array}{c}\text { Power } \\
\text { point }\end{array}$ & Film & Koran & Majalah \\
\hline Umur & 0,309 & 0,133 & 0,228 & 0,036 & 0,73 & 0,121 & $-0,94$ & 0,020 \\
\hline Pendidikan & 0,104 & $-0,026$ & $-0,186$ & $-0,083$ & $-0,160$ & 0,037 & 0,367 & 0,432 \\
\hline $\begin{array}{l}\text { Tingkat } \\
\text { Kebutuhan }\end{array}$ & a & a & a & A & A & A & A & $\mathrm{a}$ \\
\hline $\begin{array}{l}\text { Tingkat } \\
\text { kekosmolitan }\end{array}$ & 0,078 & 0,075 & 0,250 & 0,364 & $-0,047$ & 0,181 & $-0,312$ & $-0,508$ \\
\hline $\begin{array}{l}\text { Tingkat } \\
\text { keinovatifan }\end{array}$ & 0,132 & 0,121 & 0,093 & 0,051 & 0,223 & 0,551 & 0,137 & 0,121 \\
\hline
\end{tabular}


Hasil analisis hubungan faktor eksternal pembudidaya ikan (pelaku utama) dengan penggunaan media penyuluhan disajikan pada Tabel 5.

Berdasarkan data hasil analisis pada Tabel 5, materi penyuluhan menunjukkan hubungan yang erat dengan penggunaan media dalam bentuk brosur dengan korelasi 0,263** dan media penyuluhan dalam bentuk film dengan korelasi 0,364**. Sedangkan tidak menunjukkan hubungan antara materi penyuluhan dengan penggunaan media dalam bentuk folder, leaflet, peta singkap, power point, koran dan majalah. Pengaruh media massa memiliki banyak persepsi tentang jangkauannya dalam mempengaruhi pikiran dan tindakan manusia.

Sekitar tahun 1940-an dianggap bahwa media dapat memberikan pengaruh yang besar. Pendapat demikian merujuk pada kekuasaan yang dicapai oleh Hitler di Jerman. Pada tahun 1950-an menunjukkan bahwa media memiliki pengaruh yang hanya terbatas dalam pemilihan presiden di Amerika Serikat. Joseph Klapper dalam bukunya yang berjudul The Effects of Mass Communication pada tahun 1960, antara lain menganalisis beberapa proses selektif yang dapat menyebabkan keterbatasan pengaruh tersebut di dalam keadaan tertentu. Terlihat bahwa prinsip persepatual dapat digunakan untuk menarik perhatian, dan media penting untuk menyadarkan akan adanya inovasi di samping untuk mendorong minat. Media massa juga mampu mempercepat proses perubahan, tetapi jarang dapat mewujudkan perubahan dalam prilaku. Hal ini disebabkan karena pengirim dan penerima pesan cenderung menggunakan roses-proses selektif saat menggunakan media massa sehingga pesan pengirim mengalami distorsi. Dampak media massa terhadap populasi masyarakat pedesaan, memiliki peran penting dalam memperkenalkan pengetahuan, pendapat, dan hiburan yang berasal dari luar lingkungannya (Van Den Ban dan Hawkins, 1999).

Pada hasil penelitian menunjukkan bahwa media Film/Video menunjukkan hubungan yang sangat erat, hal ini sejalan dengan penelitian sebelumnya yang menyatakan bahwa secara umum karakteristik media berupa video dapat menyajikan gambar yang realistik dan memiliki kemampuan untuk memanipulasi perspektif ruang dan waktu. Secara khusus karakteristik yang ditimbulkan oleh penggunaan media audio visual adalah: (a) mampu menambah atau mengurangi waktu sesuai dengan kebutuhan untuk dapat mengamati sesuatu kejadian; (b) memiliki kemampuan mengkompresi waktu yang dibutuhkan dalam mengamati suatu kejadian; (c) kemampuan untuk memperpanjang gerakan dengan cara melambatkan gerakan, sehingga dapat ditangkap oleh mata; (d) mampu menghidupkan kembali suatu peristiwa masa lalu; (e) penguasaan ketrampilan fisik memerlukan pengamatan berulang dan latihanuntuk dapat ditiru; (f) kemampuan potensial terhadap aspek

Tabel 5. Hubungan faktor eksternal dengan penggunaan media

\begin{tabular}{|c|c|c|c|c|c|c|c|c|}
\hline F.Ekternal & Brosur & Folder & Leaflet & $\begin{array}{c}\text { Peta } \\
\text { singkap }\end{array}$ & $\begin{array}{c}\text { Power } \\
\text { point }\end{array}$ & Film & Koran & Majalah \\
\hline Materi & $0,263^{* *}$ & 0,304 & 0,278 & 0,364 & $-0,062 a$ & $0,364^{* *}$ & $-0,262$ & $-0,424$ \\
\hline $\begin{array}{l}\text { Kemasan } \\
\text { media }\end{array}$ & $-0,225$ & $-0,229$ & 0,009 & 0,179* & $0,362 \mathrm{a}$ & 0,126 & $-0,121$ & $-0,147$ \\
\hline $\begin{array}{l}\text { Penyajian } \\
\text { media }\end{array}$ & 0,015 & 0,050 & $0,259 *$ & 0,192* & $0,008 \mathrm{a}$ & 0,008 & $-0,013$ & $0,006 *$ \\
\hline
\end{tabular}


emosional, dapat digunakan untuk mengasah kepribadian dan sikap sosial; dan (g) penyajian dramatisasi yang berakhir terbuka akan memberi kesempatan kepada peserta didik untuk berdiskusi mengenai akhir se gmen. Komunikasi akan dianggap efektif atau berhasil, jika seluruh khalayak yang dilibatkan itu dapat menunjukkan pemahaman mereka tentang subjek yang disampaikan, setelah presentasi berakhir.

Kemasan media penyuluhan menunjukkan hubungan yang erat dengan penggunaan media penyuluhan berupa peta singkap dengan korelasi 0,179*. Sedangkan tidak menunjukkan hubungan kemasan media penyuluhan dengan penggunaan media penyuluhan berupa brosur, folder, leaflet, power point, film, koran dan majalah.

Penyajian media penyuluhan menunjukkan hubungan yang erat dengan penggunaan media penyuluhan berupa leaflet, peta singkap dan majalah dengan masing-masing korelasi 0,259*, 0,192* dan 0,006*. Menurut Fachry (2011) Media yang tepat sasaran akan mempermudah tercapainya tujuan. Keberhasilan suatu kegiatan menggunakan media dapat diukur dengan menilai tingkat efektifitas media yang digunakan oleh masyarakat. Sedangkan tidak menunjukkan hubungan antara penyajian media penyuluhan dengan penggunaan media dalam bentuk brosur, folder, power point, film dan koran.

Studi tentang jaringan komunikasi menunjukkan bahwa masyarakat petani di Indonesia sudah terbiasa menerima informasi melalui media elektronik, selain media personal dan media cetak (Anthy, 2002; Sopiana, 2002; Ellyta, 2006 dalam Hubeis, 2016). Salah satu media massa yang praktis dan mudah digunakan dalam penyampaian informasi pembangunan adalah media video dalam bentuk piringan $C D$ (Littlejhon, 2001 dalam Hubeis, 2016). Video sebagai media instruksional dapat menunjukkan cara penggunaan suatu produk tahap demi tahap dan sekaligus menggugah perasaan dan menarik minat dengan tujuan terjadi perubahan perilaku (Laura, 2002; Devito, 2001 dalam Hubeis, 2016).

\section{Simpulan dan Saran}

Simpulan

1. Faktor internal berhubungan dengan faktor eksternal pembudidaya ikan tingkat pendidikan, tingkat kekosmopolitan dan tingkat keinovatifan. Sedangkan faktor eksternal pembudidaya yang berhubungan dengan faktor internal adalah materi penyuluhan, kemasan penyuluhan dan penyajian penyuluhan

2. Faktor internal pembudidaya ikan (umur, pendidikan, tingkat kebutuhan, tingkat kekosmolitan dan tingkat keinovatifan) tidak menunjukkan hubungan dengan penggunaan media penyuluhan baik berupa media cetak maupun media tertayang.

3. Faktor Eksternal yang mempunyai hubungan sangat erat dengan penggunaan media penyuluhan yaitu untuk materi berhubungan erat dengan penggunaan media brosur dan film. Faktor eksternal kemasan media berhubungan dengan penggunaan media peta singkap. Sedangkan faktor eksternal penyajian media penyuluhan berhubungan erat dengan penggunaan media penyuluhan berupa leaflet, peta singkap dan majalah.

Saran

1. Penggunaan/pemilihan media penyuluhan harus sesuai dengan kebutuhan sasaran dan sumberdaya di lokasi penyuluhan.

2. Proses penyampaian pesan/informasi teknologi/pembelajaran dalam kegiatan penyuluhan dengan penggunaan media harus jelas dan menarik dan interaktif, sehingga 
dapat meningkatkan kualitas pesan yang disampaikan

\section{Daftar Pustaka}

Anonimous. Undang-Undang No. 16 tahun 2006. Sistem Penyuluhan Pertanian, Perikanan dan Kehutanan

Anonimous. Peraturan Menteri Negara Pendayagunaan Aaparatur Negara Nomor PER/19/M.PAN/10/2008 Tentang Jabatan fungsional penyuluh perikanan dan angka kreditnya.

Anthy, K. 2002. Hubungan antara Jaringan Komunikasi dengan Sikap Petani terhadap SUTPA/Sistem Usaha Tani Berbasis Padi Berorientasi Agribisnis (Kasus 2 Kelompok Tani pada Sebuah Desa di Kecamatan Ciranjang, Kabupaten Cianjur, Jawa Barat). Tesis. Institut Pertanian Bogor

Chianu, J.N. dan H.Tsujii. 2005. "Determinats of Farmers' Decesion to Adopt or Not Adopt Inorganic Fertilizer in The Savannas of Nothern Nigeria." Nutrient Cycling in Agroecosystems 70:293-301.

De Vito, Joseph A. 2001. Human Communication: The Basic Course. Harper Collins College Publishers.

Ellyta. 2006. Analisis Jaringan Komunikasi Petani dalam Pemasaran Lidah Buaya. Tesis. Institut Pertanian Bogor.

Fachry ME, Amalia Permatasari. 2011. Analisis Efektifitas Metode Penyuluhan pada Masyarakat Pesisir di Kabupaten Pangkep Sulawesi Selatan. Jurnal Agribisnis Vo. X (3) September 2011. Universitas Hasanuddin Makassar.

Kposowa, J.F. 1996. "Factors Influencing farmers in Adopting Soil Fertilization Practices:A Study of Vegetable Farmers in Prince George's County, Maryland." Unpublished $\mathrm{PhD}$, University of Maryland College, United State

Liou, Jaeik. 2004. "Community Capacity Building to Strengthen Socio-Economic Development with Spatial Asset Mapping." 3 rd FIG Regional Conference, Jakarta, Indonesia, October 3-7, 2004.

Littlejohn, Stephen, W. 2001. Theories of Human Communication 7ed. Belmont, California Wards Worth Publishing Co.
Mardikanto T. 2009. Sistem Penyuluhan Pertanian. Surakarta: Sebelas Maret University Press.

Milen, Anneli. 2001. "What Do We Know about Capacity Building. An Overview of Existing Knowladge and Good Practice ", Geneva

Sigel S. 1956. Nonparametric Statistics for Behavioral Sciences. Tokyo: Mc.Graw Hill-Kogakusha. Ltd

Singarimbun, M. dan Effendi, S. Editor. 1989. Metode Penelitian Survei. Jakarta: Lembaga Penelitian, Pendidikan, dan Penerangan Ekonomi dan Sosial.

Sopiana. 2002. Hubungan Karakteristik Petani dan Jaringan Komunikasi dengan Perilaku Usahatani Tebu. Tesis. Institut Pertanian Bogor.

Van Den Ban AW, Hawkins HS. 1999. Penyuluhan Pertanian. Yogyakarta: Kanisius. 